\title{
Koneksi Matematis pada Pembelajaran Matematika Materi Logaritma Siswa Kelas X
}

\author{
Ika Ujiana Sugianto ${ }^{1}$, Abd. Qohar ${ }^{2 *}$ \\ 1,2 Universitas Negeri Malang \\ *abd.qohar.fmipa@um.ac.id
}

\begin{abstract}
ABSTRAK
Koneksi matematis merupakan salah satu kemampuan yang penting untuk dimiliki siswa dalam belajar matematika. Dengan kemampuan koneksi, siswa dapat menghubungkan antar konsep matematika, antara konsep matematika dengan ilmu lain dan dengan dunia nyata. Artikel ini berisi hasil penelitian yang bertujuan untuk mendeskripsikan kemampuan koneksi matematis siswa dalam pembelajaran di kelas pada materi logaritma. Jenis penelitian ini adalah deskriptif kualitatif. Penelitian dilakukan dalam bentuk observasi dan analisis pada pelaksanaan pembelajaran dengan subjek penelitian adalah siswa kelas X SMAN Taruna Nala Malang sebanyak 30 siswa. Pengumpulan data dilakukan dengan cara observasi pada proses pembelajaran di kelas. Data hasil observasi kemudian dianalisis secara deskriptif. Hasil penelitian menunjukkan bahwa siswa memiliki kemampuan koneksi matematis yang baik pada saat proses pembelajaran berlangsung. Siswa dapat mengaitkan materi logaritma dengan materi matematika yang lain serta dapat mengaitkan materi matematika dengan suatu permasalahan dalam kehidupan sehari-hari.
\end{abstract}

Kata kunci: pembelajaran matematika, koneksi matematis, logaritma.

\section{ABSTRACT}

Mathematical connection is one of the important abilities for students to have in learning mathematics. With the ability to connect, students can connect between mathematical concepts, between mathematical concepts with other sciences and with the real world. This article contains the results of research on students' mathematical connection skills in classroom learning on logarithmic material. This type of research is descriptive qualitative. The study was conducted in the form of observations on the implementation of learning with research subjects were students of Taruna Nala Malang Senior High School as many as 30 students. Data collection is done by analyzing the results of student work supported by observation in the learning process in class. The results showed that students had good mathematical connection skills during the learning process. Students can associate logarithmic material with other mathematical material and can associate mathematical material with a problem in daily life.

Keywords: mathematics learning, mathematical connections, logarithms. 


\section{PENDAHULUAN}

Matematika merupakan pengetahuan yang memiliki peranan penting dalam rangka pembentukan sikap dan pola pikir siswa (Suherman, 2003), sehingga matematika menjadi salah satu pelajaran penting di sekolah. Pembelajaran matematika di kelas pun berpengaruh dalam pembentukan kognitif anak, sehingga ada beberapa pendapat bahwa pembelajaran matematika menunjang prestasi siswa. Dalam proses belajar matematika, siswa belajar untuk memahami konsep matematika melalui pengalaman tentang sifat-sifat yang dimiliki dan yang tidak dimiliki dari sekumpulan objek (abstraksi). Dalam buku Principle and Standards for School Mathematics dijelaskan bahwa standar yang perlu ada di dalam pembelajaran matematika terdiri dari standard isi (mathematical content) dan standar proses (mathematical processes). Standar proses sendiri mempunyai pengertian yaitu suatu proses yang digunakan untuk memperoleh dan menerapkan isi dari suatu pengetahuan (NCTM, 2000). Salah satu proses yang termuat di dalamnya yaitu koneksi (connections).

Masalah koneksi matematis telah lama diteliti. W.A. Brownell tahun 1930 telah meneliti koneksi matematis, namun hanya terbatas pada koneksi pada aritmetik (Bergeson, 2000: 37). Hendriana (Hendriana, 2014) dalam penelitiannya menunjukkan bahwa siswa dengan kemampuan awal matematika yang baik akan mempunyai kemampuan koneksi matematis yang baik pula. Menanti (Menanti et al., 2018) dalam penelitiannya berhasil menunjukkan adanya peningkatan kemampuan koneksi matematis dengan pembelajaran matematika realistic. Lelu \& Kurniawati (2017) telah meneliti tantang kemampuan koneksi matematis siswa SMP. Dalam penelitiannya 2 dari 5 siswa yang diteliti memiliki kemampuan koneksi matematis yang bagus (Lelu \& Kurniawati, 2017).

Bruner dan Kenney (1963), dalam Bell (1978: 143-144), mengemukakan teorema koneksi yang harus ada dalam proses belajar matematika. Adanya teorema koneksi sebagai salah satu teorema dalam proses belajar matematika menjadikan kepemilikan kemampuan koneksi pada diri siswa harus diperhitungkan. Terlebih dalam pembelajaran matematika yang erat hubungannya dengan keterkaitan diantara masing-masing materinya. Bahkan tidak hanya keterkaitan antara materi-materi matematika, tetapi juga mengakitkan materi matematika dengan berbagai permasalahan di kehidupan sehari-hari. Banyak masalah sehari-hari yang bisa diselesaikan dengan menggunakan konsep-konsep matematika. Beberapa peneliti menunjukkan hasil tentang manfaat matematika dalam kehidupan sehari-hari, antara lain (Ivorra et al., 2020; Kim \& Jung, 2019) yang meneliti tentang model matematika pada penyebaran virus Covid-19 dan virus H1N1, (Sigal et al., 2019) meneliti tentang terapi stem cell menggunakan model matematika, serta (Rudokas et al., 2019) yang meneliti tentang implementasi matematika pada sosio-ekonomi. Penelitian-penelitian tersebut menunjukkan koneksi matematika dalam kehidupan sehari-hari.

Kemampuan koneksi merupakan kemampuan untuk mengaitkan antar konsep-konsep matematika, maupun antar konsep matematika dengan konsep bidang lain dan kehidupan sehari-hari. Siswa yang memiliki kemampuan koneksi ditandai dengan tercapainya standar proses koneksi, yaitu siswa dapat: (1) mengenali dan menggunakan koneksi pada konsepkonsep matematika yang sedang dihadapi, (2) memahami bagaimana konsep-konsep matematika saling berhubungan serta terhubung antara satu dengan yang lain untuk 
menghasilkan konsep secara umum yang koheren, dan (3) mengenali serta menerapkan matematika dalam konteks diluar matematika (NCTM, 2000).

Pada saat siswa bisa menghubungkan antar konsep-konsep matematika, pemahaman mereka dianggap lebih mendalam. Siswa bisa mengamati koneksi matematika dalam interaksi yang beragam di antara topik-topik matematika yang sedang dipelajari. Hal tersebut juga terjadi dalam suatu pembelajaran matematika yang sudah diamati oleh peneliti. Bagi siswa kelas X, untuk mempelajari materi logaritma membutuhkan kemampuan koneksi yang lebih. Materi logaritma erat hubungannya dengan bentuk eksponen atau perpangkatan. Untuk mengerjakan soal materi logaritma yang berkaitan dengan penyederhanaan bentuk logaritma, siswa dilibatkan dengan berbagai macam sifat dari logaritma sehingga siswa perlu memahami hubungan diantara beberapa sifat kemudian menggunakannya untuk menyelesaikan soal yang diberikan.

Materi logaritma merupakan salah satu materi yang dianggap sulit oleh siswa. Selain kesulitan untuk memahami konsepnya, siswa juga kesulitan untuk menghubungkan antara konsep-konsep logaritma dengan konsep ilmu lain maupun dengan dunia luar. Oleh karena itu, berdasarkan latar belakang yang sudah diuraikan serta pentingnya kemampuan koneksi matematis tersebut mendorong peneliti untuk melakukan penelitian tentang bagaimana proses koneksi matematis siswa pada pembelajaran materi logaritma

\section{METODE}

Penelitian ini adalah penelitian deskriptif kualitatif, yang bertujuan untuk mendiskripsikan standar proses koneksi pada pembelajaran matematika materi logaritma. Peneliti merancang pembelajaran kemudian menerapkan pembelajaran tersebut pada siswa kelas X.

Penelitian dilakukan pada siswa kelas X SMA Taruna Nala Malang sejumlah 30 orang. Guru membagi siswa ke dalam 7 kelompok yang masing-masing kelompok terdiri dari 4-5 orang. Kemudian guru menjelaskan materi terkait yaitu logaritma sesuai RPP yang telah dibuat. Guru menjelaskan apersepsi mengenai keterkaitan logaritma dan eksponen serta mengingatkan kembali sifat-sifat logaritma yang telah dibahas pada pertemuan sebelumnya. Guru melakukan tanya jawab mengenai materi terkait dalam apersepsi, kemudian guru membagikan LKS pada masing-masing kelompok.

Pada LKS termuat soal uraian singkat yang mengkoneksikan antar sifat-sifat logaritma yang terdapat pada materi persamaan logaritma (Gambar 1), beberapa soal memasangkan (Gambar 2), dan soal implikasi logaritma pada kehidupan sehari-hari (Gambar 3). Kemudian hasil observasi dan pekerjaan siswa akan dianalisis berdasarkan standar proses koneksi matematis beserta teori-teori terkait. Standar proses koneksi matematis yang digunakan mengacu pada standar proses NCTM 2000 yang sudah dijelaskan di bagian pendahuluan.

2. Tentukan nilai $x$ yang memenuhi persamaan

$$
{ }^{3} \log \left(\frac{x^{2}-5}{3 x-5}\right)={ }^{3} \log 4
$$

Gambar 1. Soal Tentang Persamaan Logaritma 

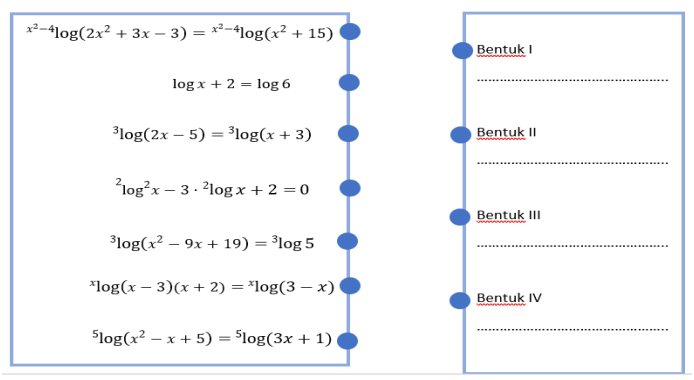

Gambar 2. Soal Memasangkan Bentuk Persamaan Logaritma dan Contohnya

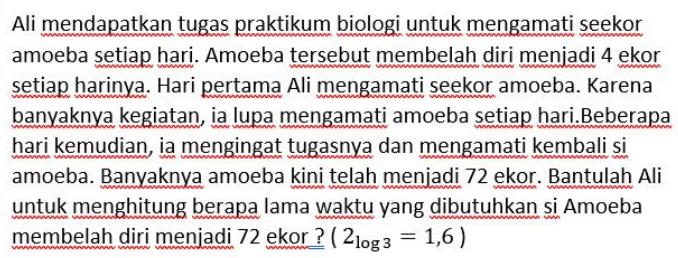

Gambar 3. Soal Penerapan Logaritma dalam Kehidupan Sehari-Hari

\section{HASIL DAN PEMBAHASAN}

Ketika proses pembelajaran berlangsung peneliti melakukan interaksi pada siswa melalui tanya jawab. Hal ini dilakukan pada bagian apersepsi. Peneliti memberikan beberapa contoh soal logaritma, kemudian beberapa siswa dipersilahkan maju kedepan untuk menuliskannya dalam bentuk eksponen. Ketika proses tersebut berlangsung, siswa dapat mengenali bahwa bentuk logaritma dapat diubah dalam bentuk eksponen sehingga siswa dapat menyelesaikan masalah yang diberikan peneliti.

Kemudian ketika diingatkan kembali mengenai sifat-sifat logaritma, peneliti kembali memberikan sebuah permasalahan, dimana siswa diminta untuk menyelesaikannya di depan kelas. Soal yang diberikan merupakan soal penerapan dari beberapa sifat-sifat logaritma yang telah dijelaskan sebelumnya. Siswa menyelesaikan soal dengan mengaitkan beberapa sifat yang diketahui. Setelah dilakukan tanya jawab pendek, diketahui bahwa siswa memahami bahwa beberapa sifat dari logaritma dapat menjadi bentuk logaritma baru yang merupakan sebuah kesatuan yang koheren.

Kemudian siswa diminta untuk mengerjakan LKS yang diberikan oleh peneliti dimana soal tersebut merupakan permasalahan bidang biologi, yaitu tentang pertumbuhan amoeba yang membelah diri. Pada kasus tersebut, respon siswa beraneka ragam, ada siswa yang dapat mengaitkannya kedalam bidang matematika menggunakan peran eksponen saja, kemudian siswa bingung untuk mencari solusinya sehingga perlu bimbingan dari guru. Di lain sisi ada siswa yang kebingungan untuk mengaitkannya dengan bentuk eksponen, tetapi setelah mengetahui bentuk eksponennya ia dapat menentukan selesaiannya menggunakan logaritma. Kemudian siswa dipersilahkan untuk melakukan diskusi kelompok sembari mengerjakan LKS tentang materi persamaan logaritma.

Berdasarkan hal tersebut dapat kita lihat pada bagian apersepsi siswa dapat mengenali bahwa bentuk logaritma dapat diubah dalam bentuk eksponen. Dibuktikan dengan siswa dapat 
menyatakan bentuk eksponen yang setara dari bentuk logaritma yang diberikan oleh guru. Hal ini menunjukkan bahwa siswa telah melakukan standar koneksi yang pertama yaitu siswa mengenali dan menggunakan koneksi pada ide-ide matematika yang sedang dihadapi. Siswa dapat menuliskan representasi berupa symbol di depan kelas, yang sebenarnya abstrak dan hanya ada di dalam pemikiran siswa. Hal ini sesuai dengan pernyataan Hodgson (1995:14) yaitu koneksi yang muncul diantara proses dan konsep dalam matematika merupakan objek abstrak yang terjadi dalam pikiran siswa.

Selain itu pelaksanaan standar proses pertama muncul kembali ketika siswa mengerjakan tugas 2 pada LKS. Setelah siswa mencari informasi tentang bentuk-bentuk dari persamaan logaritma, siswa diminta untuk mengerjakan LKS yaitu memasangkan beberapa persamaan yang ada di kolom sebelah kiri ke bentuk persamaan logaritma yang ada di kolom sebelah kanan.

Dalam aktivitas ini, siswa dapat mengenali bahwa masing-masing persamaan logaritma merupakan penerapan keempat bentuk persamaan logaritma yang ada. Di sini, siswa dapat mengamati dan mengerti apa yang menjadi ciri pada masing-masing bentuk sehingga siswa dapat menghubungkan persamaan mana yang termasuk bentuk pertama, kedua, ketiga, ataupun ke empat sebagaimana yang ada pada Gambar 4.

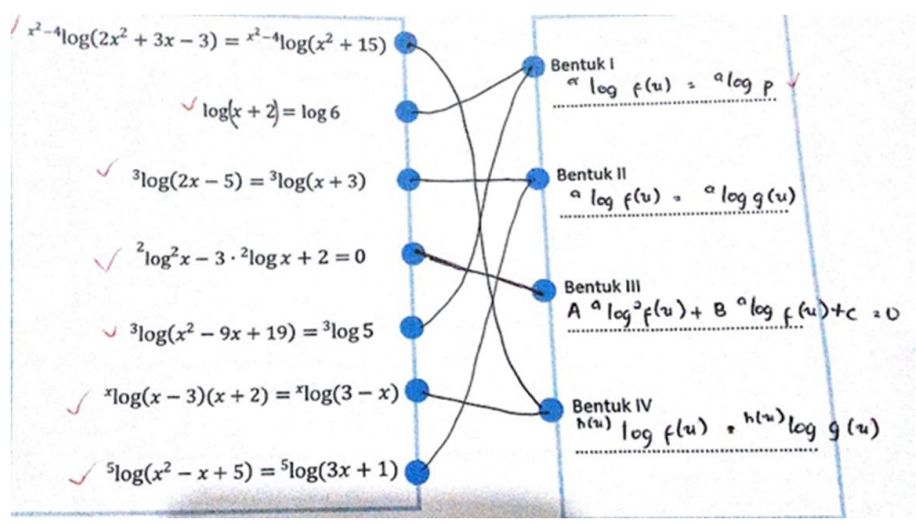

Gambar 4. Hasil Pekerjaan Siswa Tugas 2

Selanjutnya pada kegiatan tanya jawab mengenai sifat-sifat, siswa mengerti apa hubungan antara suatu bentuk logaritma dan penerapan sifatnya. Kemudian guru memberikan soal kepada siswa yang mana soal tersebut selesaiannya dapat menggunakan berbagai macam cara tergantung pada sifat apa yang akan digunakan terlebih dahulu. Siswa dipersilahkan maju kedepan dan menyelesaikannya di papan. Siswa menggunakan beberapa sifat logaritma untuk menemukan solusinya. Pada kegiatan ini, siswa secara tidak langsung telah melakukan standar proses koneksi yang kedua, yaitu siswa dapat memahami bagaimana ide-ide matematika saling berhubungan dan membangun satu sama lain untuk menghasilkan keseluruhan yang koheren. Dari berbagai sifat yang digunakan, siswa dapat menemukan hasil akhir yang merupakan solusi dari soal yang diberikan oleh guru.

Pelaksanaan standar proses kedua ini muncul kembali pada aktivitas pengerjaan LKS. Pada Tugas 3, siswa diberikan beberapa soal tentang materi persamaan logaritma. Siswa mengerjakan dengan menggunakan bentuk, sifat-sifat logaritma, dan bentuk aljabar yang telah dimengerti sebelumnya. Pertama siswa mengerjakan dengan menggunakan sifat logaritma 
terlebih dahulu, kemudia ia memisalkan bentuk logaritma dengan menggunakan variabel lain. Barulah ia menyelesaikan bentuk persamaan tersebut dengan menggunakan aljabar dan mencari nilai $x$ menggunakan ekuivalensi antara logaritma dan eksponen. Dari hasil pengerjaan siswa diketahui bahwa siswa mengerti bahwa ada keterkaitan antara bentuk persamaan, pertidaksamaan, sifat-sifat logaritma, aljabar, dan eksponen yang ada pada soal yang diberikan sebagaimana yang ada pada Gambar 5. Temuan ini berbeda dengan hasil penelitian Siregar dan Surya (2017) yang menyatakan bahwa koneksi matematis siswa SMP Muhammadiyah 22 Kisaran masih rendah, mereka masih kesulitan untuk menghubungkan antar konsep dalam matematika.

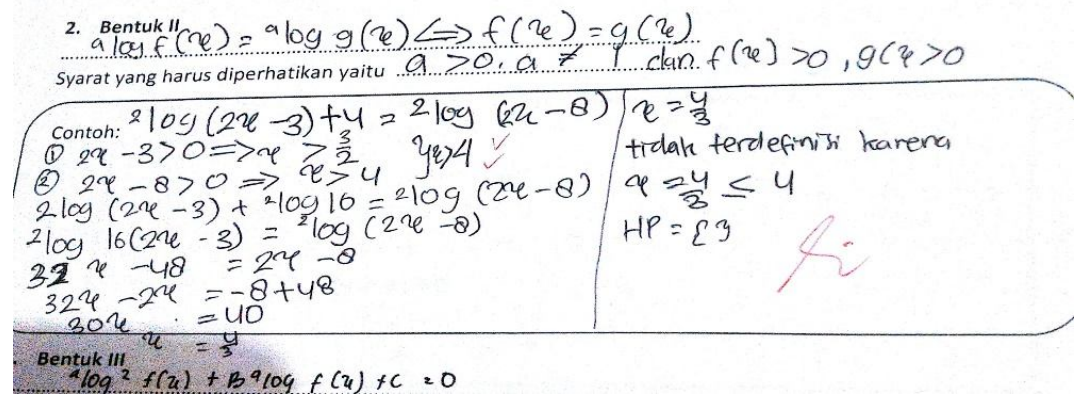

Gambar 5. Mengaitkan Materi Persamaan dan Pertidaksamaan Aljabar dalam Menyelesaikan Soal Logaritma

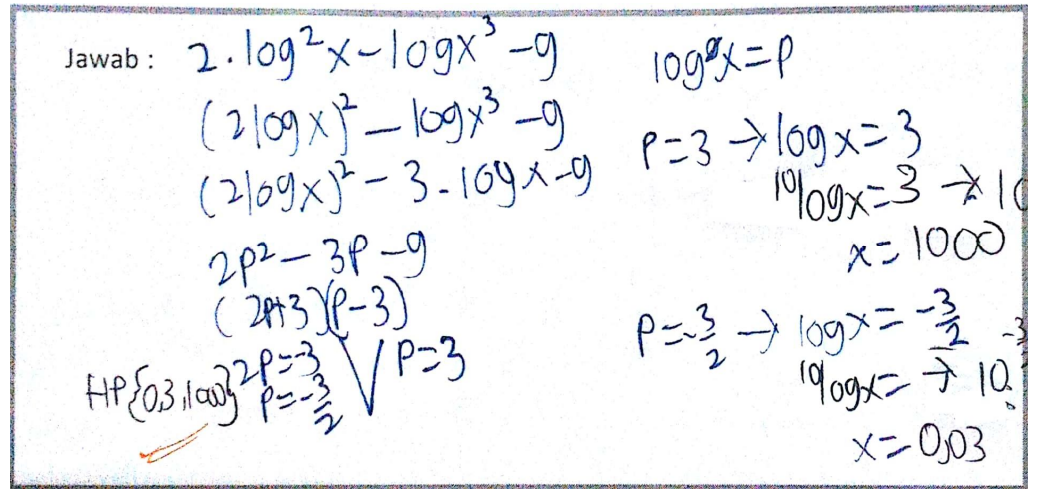

Gambar 6. Menyelesaikan Soal Menggunakan Aljabar.

Standar proses yang ketiga yaitu mengenali dan menerapkan matematika dalam konteks di luar matematika (NCTM, 2000). Ketika siswa diberikan permasalahan tersebut, siswa sedikit kebingungan dalam menyelesaikan masalah, sehingga masih perlu bimbingan dari guru. Ada siswa yang bingung untuk mengaitkan soal cerita ke dalam bentuk matematis, ada siswa yang hanya bisa mentransformasi soal cerita ke dalam tabel, menemukan pola, kemudian membuat bentuk eksponennya. Bahkan ada siswa yang awalnya ia tidak bisa mengaitkan ke dalam bentuk eksponen tetapi setelah diberikan arahan dari guru, siswa dapat menyelesaikan permasalahan yang diberikan menggunakan logaritma. Hal tersebut dapat dilihat pada Gambar 7 dan 8 .

Pada saat pembelajaran guru mencoba memberikan sebuah permasalahan biologi tentang amoeba yang membelah diri. Dengan permasalahan ini, siswa dapat mengaitkan konsep membelah diri dengan pola barisan dan kemudian menyelesaikannya dengan menggunakan logaritma. Hal ini sejalan juga dengan temuan Haji, S., Abdullah, M. I., Maizora, S. \& Yumiati (2017) yang menyatakan bahwa kemampuan koneksi matematis siswa yang belajar di luar 
ruangan lebih tinggi dibanding siswa yang belajar di dalam ruangan. Artinya dengan mengaitkan matematika dengan konteks di luar matematika, maka kemampuan koneksi matematis siswa akan meningkat.

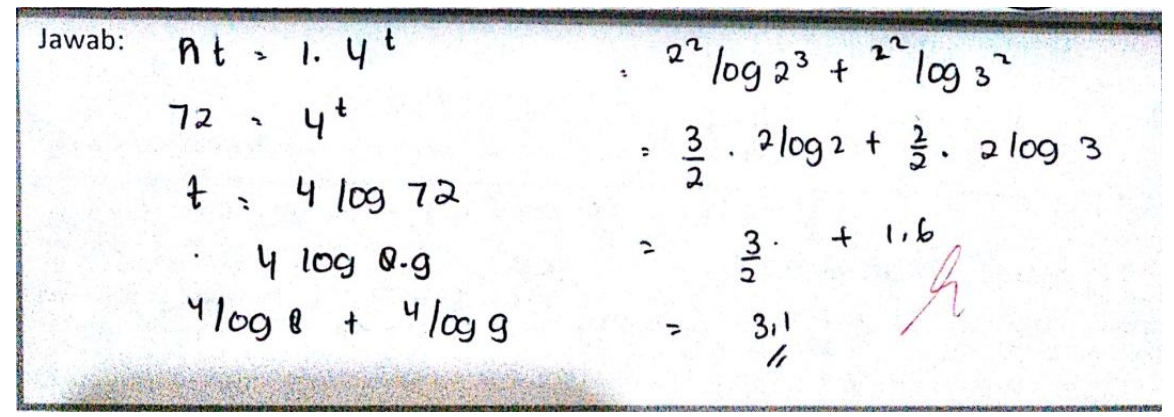

Gambar 7 . Penyelesaian Menggunakan Eksponensial dan Logaritma

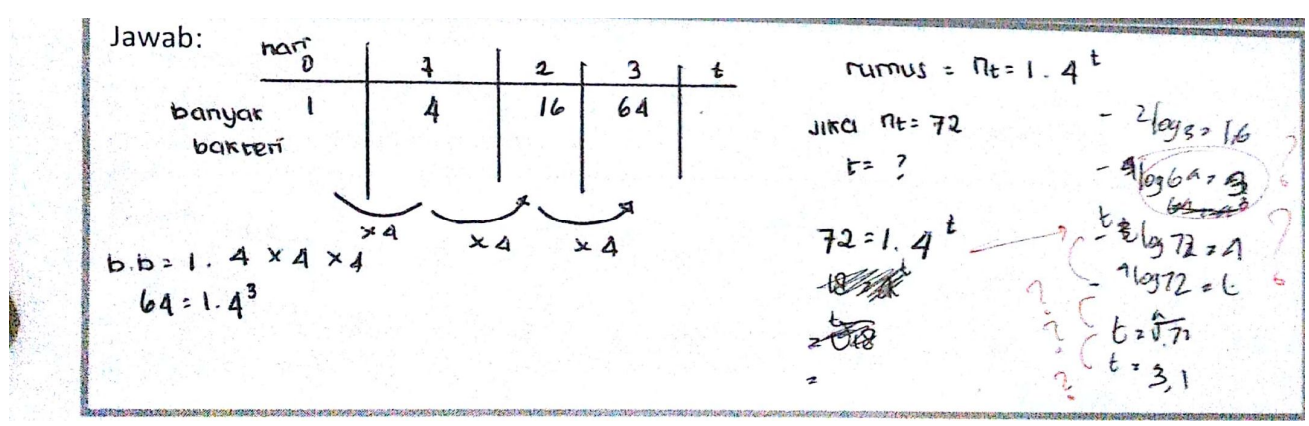

Gambar 8. Pekerjaan Siswa Menggunakan Tabel dan Pola Bilangan Serta Logaritma

\section{SIMPULAN}

Dari kegiatan pembelajaran yang dilakukan di kelas, dapat ditarik kesimpulan bahwa siswa memiliki kemampuan koneksi matematis cukup baik yang terlihat saat proses pembelajaran berlangsung. Siswa dapat mengaitkan materi logaritma dengan materi matematika yang lain serta dapat mengaitkan materi matematika dengan suatu permasalahan dalam kehidupan sehari-hari. Hal tersebut dibuktikan dengan hasil pekerjaan siswa dan observasi saat proses pembelajaran berlangsung. Siswa memenuhi ketiga standar proses sebagaimana yang dijelaskan dalam NCTM yaitu: (1) mengenali dan menggunakan koneksi pada ide-ide matematika yang sedang dihadapi, (2) memahami bagaimana ide-ide matematika saling berhubungan dan membangun satu sama lain untuk menghasilkan keseluruhan yang koheren, dan (3) mengenali dan menerapkan matematika dalam konteks diluar matematika.

Namun demikian, dalam mengaitkan permasalahan dalam kehidupan sehari-hari siswa masih belum terbiasa. Sehingga saran peneliti, untuk meningkatkan kemampuan koneksi siswa, guru perlu membuat beragam soal modifikasi non rutin yang mengaitkan materi-materi sebelumnya yang telah diketahui siswa dan memberikan bimbingan kepada siswa yang membutuhkan bimbingan lebih. 


\section{DAFTAR PUSTAKA}

Bell, Frederick H. (1978). Teaching and Learning Mathematics in Secondary School. Cetakan kedua. Dubuque, Iowa: Wm. C. Brown Company Publishers.

Bergeson, T. (2000). Teaching and Learning Mathematics: Using Research to Shift From the "Yesterday" Mind to the "Tommorow" Mind. [Online]. Tersedia: www.k12.wa.us.

Hodgson, T.(1995). Connections as Problem-Solving Tools dalam Connecting Mathematics across the Curriculum. Editor: House, P.A. dan Coxford, A.F. Reston, Virginia: NCTM.

NCTM. (2000). Principle and Standard for School Mathematics.

Suherman, Erman \& dkk. (2003). Strategi Pembelajaran Matematika Kontemporer. Bandung : Universitas Pendidikan Indonesia.

Siregar, N.D. \& Surya, E. (2017). Analysis of Students' Junior High School Mathematical Connection Ability. International Journal of Sciences: Basic and Applied Research (IJSBAR). Vol. 33, No 2, pp 309-320.

Haji, S., Abdullah, M. I., Maizora, S. \& Yumiati (2017). Developing Students' Ability of Mathematical Connection Through Using Outdoor Mathematics Learning. Infinity, 6 (1), 11-20.

Hendriana, H. (2014). MATHEMATICAL CONNECTION ABILITY AND SELFCONFIDENCE (An experiment on Junior High School students through Contextual Teaching and learning with Mathematical Manipulative). International Journal of Education, 8(1), 1-11. https://doi.org/10.17509/ije.v8i1.1726

Ivorra, B., Ferrández, M. R., Vela-Pérez, M., \& Ramos, A. M. (2020). Mathematical modeling of the spread of the coronavirus disease 2019 (COVID-19) taking into account the undetected infections. The case of China. Communications in Nonlinear Science and Numerical Simulation, 88(PG-105303-105303), 105303. https://doi.org/https://doi.org/ 10.1016/j.cnsns.2020.105303

Kim, S., \& Jung, E. (2019). Prioritization of vaccine strategy using an age-dependent mathematical model for 2009 A/H1N1 influenza in the Republic of Korea. Journal of Theoretical Biology, 479, 97-105. https://doi.org/10.1016/j.jtbi.2019.07.011

Lelu, A. M., \& Kurniawati, C. (2017). The Ability of Mathematical Connections On The Sum Of Triangle Angles By Using Problem-Based Learning For Junior High School Student. Proceedings The 2017 International Conference on Research in Education - Sanata Dharma University, 2008, 182-192.

Menanti, H., Sinaga, B., \& Hasratuddin, D. (2018). Improve Mathematical Connections Skills with Realistic Mathematics Education Based Learning. 200(Aisteel), 29-35. https://doi.org/10.2991/aisteel-18.2018.7

Rudokas, K., Landauskas, M., Gražulevičiūtè-Vilneiškè, I., \& Viliūnienė, O. (2019). Valuing the socio-economic benefits of built heritage: Local context and mathematical modeling. Journal of Cultural Heritage, 39, 229-237. https://doi.org/10.1016/j.culher.2019.02.016

Sigal, D., Przedborski, M., Sivaloganathan, D., \& Kohandel, M. (2019). Mathematical modelling of cancer stem cell-targeted immunotherapy. Mathematical Biosciences, 318, 108269. https://doi.org/10.1016/j.mbs.2019.108269 